\title{
Kawasaki Disease with Hidden Neuroblastoma
}

\author{
Gizli Nöroblastomla Birlikte Kawasaki Hastalığı
}

Ayşe Kaman ${ }^{1}$, Gönül Tanır ${ }^{1}$, Türkan Aydın Teke ${ }^{1}$, Özge Metin ${ }^{1}$ Zeynep Gökçe Gayretli Aydın ${ }^{1}$, Tutku Soyer ${ }^{2}$ Diclehan Orhan ${ }^{3}$

\footnotetext{
${ }^{1}$ Dr. Sami Ulus Maternity and Children's Training and Research Hospital, Division of Pediatric Infectious Diseases, Ankara, Turkey

${ }^{2}$ Hacettepe University School of Medicine, Department of Pediatric Surgery, Ankara, Turkey

${ }^{3}$ Hacettepe University School of Medicine, Department of Pediatric Pathology, Ankara, Turkey
}

\section{ABSTRACT}

Kawasaki disease, predominantly affecting infants and young children, is a systemic vasculitis with an unknown origin. The diagnosis of the disease is based on clinical criteria. Neuroblastoma is the most common extracranial solid tumor seen children under five years of age as Kawasaki disease. The two conditions are rarely reported together. We describe an infant who was initially diagnosed as Kawasaki disease, and thereafter neuroblastoma. It is discussed whether neuroblastoma plays any role in the pathogenesis of Kawasaki disease in this report.

Key Words: Kawasaki disease, neuroblastoma, pathogenesis, children

\section{ÖZET}

Kawasaki hastalığı henüz nedeni tam bilinmeyen, sıklıkla bebekleri ve küçük çocukları etkileyen sistemik bir vaskülittir. Hastalığın tanısı klinik kriterlere göre doğrulanır. Nöroblastom, kawasaki hastalığı gibi sıklıkla beş yaşın altındaki çocuklarda görülen çocukluk çağının en sık karnium dıiı solid tümörüdür. Bu iki hastalığın nadiren birlkite olduğu raporlanmıştır. Bu yazıda; başlangıçta Kawasaki hastalığı, daha sonra ise nöroblastom tanısı alan bir bebeği anlattık ve nöroblastomun, Kawasaki hastalığı tanısında herhangi bir rolü olup olmadığı tartıştık.

Anahtar Sözcükler: Kawasaki hastalığı, nöroblastom, patogenez, çocuk

Geliș Tarihi: 01.03.2016

Kabul Tarihi: 03.06.2016

\section{INTRODUCTION}

Kawasaki disease (KD) is an acute febrile vasculitis that generally affects children younger than five years of age (1). The exact etiology of KD is still unknown. We describe an infant who was diagnosed as KD and NB concurrently. It is questioned whether neuroblastoma played a role in the pathogenesis of KD or the two diseases were incidental in this manuscript.

\section{CASE REPORT}

A 16-month-old girl was referred to our infectious diseases department with a fever for five days. She had been diagnosed as acute fever without focus, and treated with parenteral three doses of ceftriaxone without benefit in another hospital. On admission, she was febrile and irritable. Her physical examination revealed only minimal oropharyngeal hyperemia. 
Laboratory examination of the patient was as follows; hemoglobin concentration $10.7 \mathrm{~g} / \mathrm{dL}$; white blood cell count $10,980 / \mathrm{mm}^{3}$; platelet count $285,000 / \mathrm{mm}^{3}$; erythrocyte sedimentation rate (ESR), $77 \mathrm{~mm} / \mathrm{h}(0-10 \mathrm{~mm} / \mathrm{h})$ and C-reactive protein (CRP), $77 \mathrm{mg} / \mathrm{dL}(0-8 \mathrm{mg} / \mathrm{dl})$. Alanin aminotransferase, aspartate aminotransferase and serum albumin concentration were all normal. Urinalysis revealed pyuria. Thrombocytosis $\left(592,000 / \mathrm{mm}^{3}\right)$ was observed on the $9^{\text {th }}$ day of the illness. Cultures of blood and urine were negative. Due to the persistent fever without focus for $\geq 5$ days, increased ESR and CRP levels, presence of sterile pyuria, thrombocytosis and unresponsiveness to ceftriaxone, incomplete KD was considered. Transthoracic echocardiography demonstrated dilatation $(3.8 \mathrm{~mm}$, normal: $<3 \mathrm{~mm}$ ) in her left coronary artery. Abdominal ultrasonography, revealed a $3 \times 2 \times 3 \mathrm{~cm}$ lesion including microcalcification on the right adrenal gland, surprisingly. The lesion was defined as NB or ganglioneuroblastoma (GNB) on computed tomography (CT) (Figure 1). She was treated with intravenous immunoglobulin (IVIG) at a dose of $2 \mathrm{gr} / \mathrm{kg} /$ day. Her fever resolved after the single dose of IVIG. She was referred to the pediatric surgery department for operation on the $7^{\text {th }}$ day of the admission. The histopathological examination of the tumor showed clusters of neuroblastic cells (Figure 2). More than 5\% of neuroblasts differentiated to ganglion cells. The positive staining was obtained with neuron-specific enolase, chromogranin, CD56 and PGP9.5 in immunohistochemical analysis. She was discharged from the hospital on the $5^{\text {th }}$ day postoperative. Control echocardiography demonstrated normal coronary artery diameter on follow up for six months.

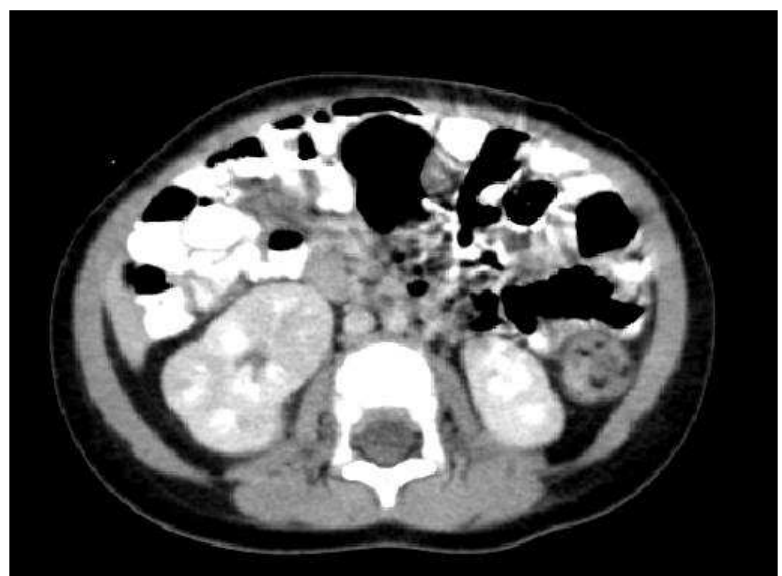

Figure 1. $3 \times 2 \times 3 \mathrm{~cm}$ sized, round lesion on the right adrenal gland of the patient

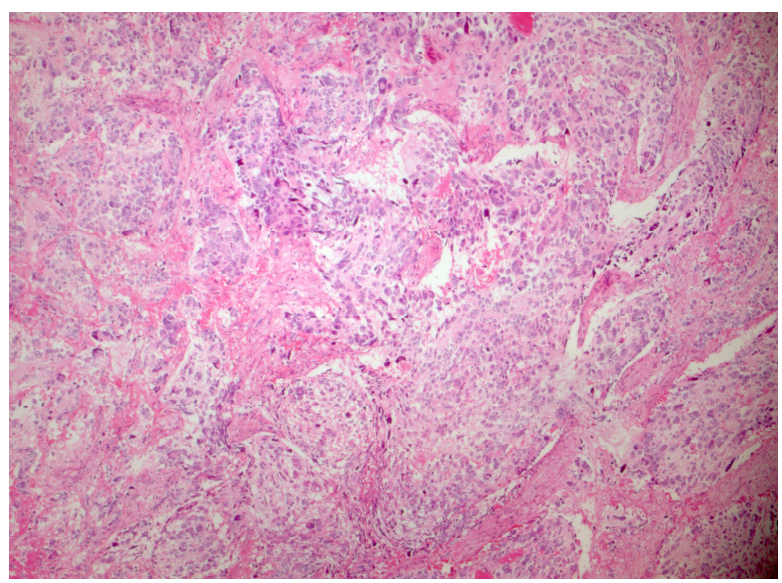

Figure 2. The histoptahologic evaluation of tumor revealed neuroblastoma with poor stromal elements. The tumor showed clusteres of neurobalstic cells

\section{DISCUSSION}

KD is the most common cause of acquired heart disease among children in developed countries. The diagnosis of the disease is based on clinical criteria (1). The patients who do not fulfill the major diagnostic criteria, but have echocardiographic findings of coronary artery abnormalities are defined as incomplete KD. The American Heart Association remarked that although classic diagnostic criteria are useful for preventing overdiagnosis, it may result in failure to recognize incomplete forms of the illness (2).
The present patient did not have sufficient clinical signs of the disease to fulfill the classic criteria, so laboratory investigations were carefully performed to support the diagnosis. Acute acalculous distention of the gallbladder was reported in approximately $15 \%$ of patients with KD (2). Abdominal ultrasonography revealed a mass lesion on surrenal gland incidentally while investigating gallbladder hydrops as a supplemental finding of $K D$ in our patient.

NB is the most common extracranial solid tumor of childhood (3). It is known that $80 \%$ of patients with NB as well as KD are diagnosed under five years of age $(1,3)$. The cases of KD associated with NB were reported previously (4-7). A 6-month- old boy who died from KD with a mass lesion in the left paravertebral region as an autopsy finding was reported in 1974 [6]. Sixty-one cases who had a past history of KD were examined in an autopsy study and it was reported that one of these cases had NB (8). A 4-month-old boy with KD who developed acute urinary retention due to pelvic NB has been reported as a first survivor (9). In another study, a 2-year-old girl had classic KD with fever did not respond to retreatment with IVIG. For this reason a chest $\mathrm{CT}$ was performed and it revealed a mass lesion which was ultimately diagnosed as NB on the paravertebral area of thoracic spine. The second patient was a 3 -year-old boy who had incomplete KD with left coronary ectasia. Since fever did not respond to retreatment with IVIG, abdominal CT with biopsy confirmed NB (5). A 2-year-old boy who had classic KD complicated with dilatation of left coronary artery was reported recently. In this case, the abdominal ultrasound-performed because of recurrent fever-revealed a mass lesion on his right adrenal gland that was finally diagnosed as NB (7). In these case studies, some authors suggest that cytokine cascade stimulation and endothelial cell activation occur in acute KD. Increased levels of vascular endothelial growth factor, monocyte chemotactic and activating factor, tumor necrosis factor, and various interleukins play important roles in the vasculitic process and such acute vasculitis effect accelerates a hidden tumor by inflammation $(2,5)$. On the other hand; it is speculated that coronary dilatation may be a result of humoral effect of NB as a paraneoplastic syndrome (7). Whereas some other authors suggest that KD and NB may be incidentally concurrent in a patient (4).

The present case of incomplete KD responded to high dose IVIG treatment without the recurrence of fever. The disease improved significantly without removal of the tumor, so it was suggested that it was more likely that cytokine cascade stimulation accelerated the development of a hidden tumor, rather than it was a paraneoplastic syndrome. The another suggestion is, KD and NB were coincidental situations rather than a causal relationship. It is concluded that clinicians should be aware because these two diseases may be concurrent in a patient.

\section{Conflict of interest}

No conflict of interest was declared by the authors

\section{REFERENCES}

1. Freeman AF, Shulman ST. Kawasaki disease: summary of the American Heart Association guidelines. Am Fam Physician 2006; 74:1141-48.

2. Newburger JW, Takahashi M, Gerber MA, et al. Diagnosis, treatment, and long-term management of Kawasaki disease: a statement for health professionals from the Committee on Rheumatic Fever, Endocarditis, and Kawasaki Disease, Council on Cardiovascular Disease in the Young, American Heart Association. Pediatrics 2004; 114:1708-33.

3. Castleberry RP. Predicting Outcome in Neuroblastoma. N Engl J Med 1999; 340:1992-3

4. Alavi S, Fahimzad A, Jadali F, Ghazizadeh F, Rashidi A. Concurrent adrenal neuroblastoma and kawasaki disease: a report of a rare case. Case Rep Pediatr 2013;931703 (2013:931703. doi: 10.1155/2013/931703)

5. Lim YJ, Jung JW, Jung HJ, Park JE. Two cases of Kawasaki disease with hidden neuroblastoma. Indian J Pediatr 2013; 80:881-8.

6. Yanagisawa M, Kobayashi N, Matsuya S. Myocardial infarction due to coronary thromboarteritis following acute febrile mucocutaneous lymph node syndrome in an infant. Pediatrics 1974; 54:277-80.

7. Zhang YT, Feng LH, Zhong XD, Wang LZ, Chang J. Kawasaki disease associated with neuroblastoma: evidence for a new paraneoplastic syndrome? Indian J Pediatr 2014; 81: 403.

8. Tanaka N, Naoe S, Masuda H, Ueno T.Pathological study of sequelae of Kawasaki disease (MCLS). With special reference to the heart and coronary arterial lesions. Acta Pathol Jpn 1986; 36: 1513-27.

9. Ohta S, Narita T, Kato H, Taga T, Takeuchi Y. A patient with Kawasaki disease who developed acute urinary retention due to pelvic neuroblastoma. Eur J Pediatr 2002; 161: 631. 